\title{
Analisa Distribusi Curah Hujan di Area Merapi Menggunakan Metode Aritmatika Dan Poligon
}

\author{
${ }^{\square}$ Lashari $^{1}$, Rini Kusumawardani ${ }^{2}$, Ferdian Prakasa ${ }^{3}$ \\ 1Jurusan Teknik Sipil, Fakultas Teknik, Universitas Negeri Semarang (UNNES)
}

\section{Kata Kunci/ Keywords :}

Hidrologi, Hujan, DAS, Merapi, Metode Aritmatika, Metode Poligon Thiessen

Hydrology, Rain, watersheds area, Merapi, Arithmetic method, Thiessen Polygon Method

\begin{abstract}
Abstrak:
Watershed (DAS) at the peak of Merapi is very interesting to examine in case of the relation with debris flow due to vomit material from Mount Merapi. In this article reveals the pattern of rainfall distribution, the difference in precipitation every month, rainfall for the period of 5 years, 10 years, 25 years, and 50 years in the area of Merapi and its effect on the behavior of a watershed in the Merapi area. In this study, the rainfall data validity test was conducted by RAPS (rescaled Adjusted Partial Sums). Analysis of the region rain is calculated using arithmetic method or average Algebra and Thiessen Polygon. While Gumbel Distribution, Normal Distribution, Log-Normal Distribution and Distribution LogPearson III was used to analyze the pattern of rainfall distribution. Furthermore, to determine the appropriate distribution patterns were analyzed using the chisquared test and test-Kolmogorof Smirnov. Calculate the intensity of rainfall at a specific time duration using the formula Mononobe.

Daerah Aliran Sungai (DAS) yang berada di puncak merapi sangat menarik untuk diteliti mengenai keterkaitannya dengan fenomena debris flow material akibat muntahan dari gunung Merapi. Pada artikel ini mengungkapkan mengenai pola distribusi curah hujan, perbedaan curah hujan setiap bulan, curah hujan untuk periode ulang 5 tahunan, 10 tahunan, 25 tahunan, dan 50 tahunan di Area Merapi dan pengaruhya terhadap perilaku DAS di area Merapi. Dalam penelitian ini uji kevalidan data hujan dilakukan dengan metode RAPS (Rescaled Adjusted Partial Sums). Analisis hujan wilayah dihitung menggunakan Metode Aritmatika atau Rata-rata Aljabar dan Poligon Thiessen. Sedangkan Distribusi Gumbel, Distribusi Normal, Distribusi Log-Normal, dan Distribusi Log-Pearson III digunakan untuk menganalisis pola distribusi curah hujan. Selanjutnya untuk mengetahui pola distribusi yang sesuai dianalisa menggunakan Uji Chi Kuadrat dan Uji Smirnov-Kolmogorof. Menghitung intensitas hujan pada durasi waktu tertentu menggunakan rumus Mononobe.
\end{abstract}

Sitasi:

Lashari, dkk. (2017). Analisa Distribusi Curah Hujan di Area Merapi Menggunakan Metode Aritmatika dan Poligon Thiessen. Jurnal Teknik Sipil \& Perencanaan, 19(1), 39 - 48.

(C) 2017 Universitas Negeri Semarang

\footnotetext{
Lashari :

Gedung E4, Kampus Sekaran

Universitas Negeri Semarang, Kota Semarang

E-mail : lashari1955@gmail.com
}

p-ISSN 1411-1772 


\section{PENDAHULUAN}

Wilayah tangkapan air hujan yang akan mengalir ke sungai yang bersangkutaan disebut Daerah Aliran Sungai (DAS) (Girsang, 2008). Adanya DAS ini diharapkan dapat dimanfaaatkan dalam penelitian tentang hidrologi karena akan bermanfaat dalam bidang pertanian, ilmu pengetahuan, infrastruktur, dan juga dapat digunakan sebagai acuan waspada bencana banjir, tanah longsor, dan kekeringan.

DAS biasanya memiliki stasiun hujan untuk mencatat data hujan. Di Indonesia, data hujan biasanya ditakar dan dikumpulkan oleh beberapa instansi, antara lain: Dinas Pengairan, Dinas Pertanian, Badan Meteorogi dan Geofisika. Penakar hujan adalah instrumen yang digunakan untuk mendapatkan dan mengukur jumlah curah hujan pada satuan waktu tertentu. Secara umum alat penakar hujan terbagi dalam tiga jenis, yaitu: jenis penakar hujan biasa tipe Obervatorium (Obs) atau konvensional, jenis penakar hujan mekanik recorder (Jenis Hellman), dan jenis penakar hujan otomatis/Otomatic Rainfall Recorder (ARR) atau penakar hujan tipping bucket.

Di area sekitar Gunung Merapi telah dipasang beberapa stasiun penangkar hujan yang bisa digunakan untuk penelitian diantaranya mengenai karakteristik hujan. Dengan pemanfaatan data yang diperoleh dari alat penangkar hujan tersebut penulis akan mengambil salah satu fokus penelitian mengenai analisa distribusi curah hujan di Area Merapi.

Hujan merupakan salah satu jenis presipitasi yang jatuh vertikal di atas permukaan bumi dan diukur oleh penakar hujan. Hujan jatuh dalam bentuk tetesan yang dikondensasikan oleh uap air di atmosfer (Seyhan, 1990).

Hujan didefinisikan sebagai bentuk air yang jatuh ke permukaan bumi. Hujan berbeda dengan gerimis, hujan memiliki diameter tetes lebih dari $0,5 \mathrm{~mm}$ dengan intensitasnya lebih dari 1,25 mm/jam, sedangkan gerimis memiliki diameter tetes kurang dari $0,5 \mathrm{~mm}$ dan memiliki intensitas kurang dari $1 \mathrm{~mm} / \mathrm{jam}$ (Tjasyono, 2004).

Durasi hujan adalah waktu yang dihitung dari saat hujan mulai turun sampai berhenti, yang biasanya dinyatakan dalam jam. Intensitas hujan rerata adalah perbandingan antara kedalaman hujan dengan intensitas hujan. misalnya hujan dalam 5 jam menghasilkan kedalaman $5 \mathrm{~mm}$, yang berarti intensitas hujan rerata adalah $10 \mathrm{~mm} / \mathrm{jam}$. Demikian juga hujan dalam 5 menit sebesar 6 $\mathrm{mm}$, yang berarti intensitas reratanya adalah $72 \mathrm{~mm} / \mathrm{jam}$. Analisis untuk menghitung jumlah curah hujan dalam satu satuan waktu, yang biasanya dinyatakan dalam $\mathrm{mm} / \mathrm{jam}, \mathrm{mm} / \mathrm{hari}$, $\mathrm{mm} /$ bulan, $\mathrm{mm} /$ tahun dan sebagainya, yang berturut-turut sering disebut hujan jam-jaman, harian, mingguan, bulanan, tahunan dan sebagainya disebut dengan intensitas hujan (Triatmodjo, 2013).

\section{METODE PENELITIAN Lokasi Penelitian}

Lokasi penelitian dilakukan di area Gunung Merapi meliputi Kabupaten Sleman, Provinsi Daerah Istimewa Yogyakarta, serta Kabupaten Magelang, Kabupaten Boyolali dan Kabupaten Klaten, Provinsi Jawa Tengah, dengan 11 stasiun hujan yaitu, stasiun hujan Jrakah, stasiun hujan Ketep, stasiun hujan Ngandong, stasiun hujan Plosokerep, stasiun hujan Pucanganom, stasiun hujan Randugunting, stasiun hujan Sopalan, stasiun hujan Sorasan, stasiun hujan Talun, stasiun hujan Stabelan, dan stasiun hujan Sukorini.

\section{Metode Analisa Data}

Analisa data menggunakan metode aritmatika atau rata-rata aljabar dan isohyet untuk menentukan curah hujan wilayah. Metode Gumbel, Normal, Log-Pearson III, dan Log-Normal digunakan untuk menentukan periode distribusi hujan tahunan. Sedangkan untuk menentukan pola distribusi yang sesuai menggunakan Uji Chi-Kuadrat dan Uji Smirnov-Kolmogorof.

\section{Alat Analisa Data}

Pengelolaan peta DAS dan pembuatan peta wilayah aritmatika dan isohyets menggunakan AutoCAD, pengelolaan data hujan menggunakan Microsoft Excel,, dan pembuatan peta distribusi curah hujan menggunakan ArcGIS.

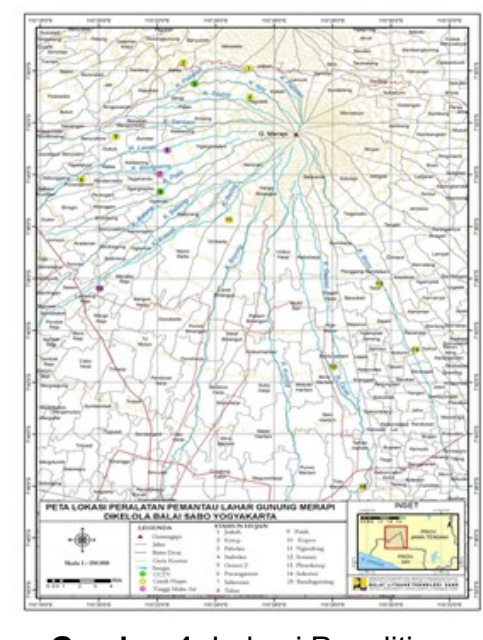

Gambar 1. Lokasi Penelitian 


\section{HASIL PEMBAHASAN \\ Uji Kevalidan Data}

Data yang diperoleh dari stasiun hujan perlu diuji karena ada kemungkinan data tidak valid akibat alat pernah rusak, alat pernah berpindah tempat, lokasi alat terganggu, atau data tidak sah. Uji kevalidan dalam penelitian ini dilakukan dengan cara RAPS (Rescaled Adjusted Partial Sums). Bila Q/Vn yang didapat lebih kecil dari nilai kritik untuk tahun dan confidence level yang sesuai, maka data dinyatakan panggah (Agustin, 2010).

Uji kevalidan dapat dilakukan dengan menggunakan persamaan-persamaan berikut:

$$
\begin{aligned}
& S_{k}^{*}=\sum_{i=1}^{k}\left(Y_{i}-\bar{Y}\right), \text { dengan } \mathrm{k}=1,2,3, \ldots, \mathrm{n} \\
& S_{k}^{*}=0 \\
& S_{k}^{* *}=\frac{S_{k}^{*}}{S D}, \text { dengan nilai } \mathrm{k}=0,1,2,3, \ldots, \mathrm{n} \\
& S D^{2}=\sum_{i=1}^{n} \frac{\left(Y_{i}-\bar{Y}\right)^{2}}{n}
\end{aligned}
$$

Dengan:

$\begin{array}{ll}Y_{i} & =\text { Data hujan ke-i, } \\ \bar{Y} & =\text { Data hujan rerata- } i, \\ \text { SD } & =\text { Deviasi standar/ Standar deviasi } \\ n & =\text { Jumlah data } \\ \text { Untuk } & \text { uji kepanggahan digunakan cara } \\ \text { statistic: }\end{array}$

$Q=\operatorname{maks}\left|S_{k}^{* *}\right|, 0 \leq k \leq n$, atau

$\mathrm{R}=$ maksimum $S_{k}^{* *}-\operatorname{minimum} S_{k}^{* *}$, dengan $0 \leq k \leq n$

Nilai kritik $Q$ dan $R$ ditunjukan dalam tabel sebagai berikut:

Tabel 1. Nilai Kritik $Q$ dan $R$

\begin{tabular}{ccccccc}
\hline \multirow{3}{*}{$n$} & \multicolumn{3}{c}{$\frac{Q}{\sqrt{n}}$} & \multicolumn{4}{c}{$\frac{R}{\sqrt{n}}$} \\
\cline { 2 - 7 } & $90 \%$ & $95 \%$ & $99 \%$ & $90 \%$ & $95 \%$ & $99 \%$ \\
\hline 10 & 1.05 & 1.14 & 1.29 & 1.21 & 1.28 & 1.38 \\
\hline 20 & 1.10 & 1.22 & 1.42 & 1.34 & 1.43 & 1.60 \\
\hline 30 & 1.12 & 1.24 & 1.46 & 1.40 & 1.50 & 1.70 \\
\hline 40 & 1.13 & 1.26 & 1.50 & 1.42 & 1.53 & 1.74 \\
\hline 50 & 1.14 & 1.27 & 1.52 & 1.44 & 1.55 & 1.78 \\
\hline 100 & 1.17 & 1.29 & 1.55 & 1.50 & 1.62 & 1.86 \\
\hline$\infty$ & 1.22 & 1.36 & 1.63 & 1.62 & 1.75 & 2.00 \\
\hline
\end{tabular}

Data hujan diambil di 11 stasiun hujan dari bulan Januari 2015 sampai dengan bulan
Maret 2016. Data dari stasiun dinyatakan valid apabila nilai $Q / \sqrt{ }$ n yang didapat lebih kecil dari nilai $Q_{\text {kritik }}$. Nilai $Q_{\text {kritik }}$ didapat dari tabel nilai kritik dengan $\mathrm{n}=15$ dan Confidence Interval $90 \%$. Setelah dilakukan interpolasi besaran nilai kritik untuk stasiun hujan adalah $Q_{\text {kritik }}=$ 1,22 .

Tabel 2. Hasil Uji Kevalidan Semua Stasiun Hujan di Area Merapi

\begin{tabular}{cc}
\hline Stasiun & Keterangan \\
\hline Stabelan & Tidak Valid \\
Jrakah & Valid \\
Ketep & Valid \\
Talun & Valid \\
Pucang anom & Valid \\
Ngandong & Valid \\
Sopalan & Valid \\
Sorasan & Valid \\
Randugunting & Valid \\
Sukorini & Tidak Valid \\
Plosokerep & Valid \\
\hline
\end{tabular}

Dari hasil rekap uji kevalidan pada Tabel 2 diketahui bahwa data hujan di stasiun hujan Stabelan dan stasiun hujan Sukorini tidak valid. Oleh sebab itu data hujan di stasiun hujan Stabelan dan stasiun hujan Sukorini tidak dipakai dalam analisis selanjutnya.

\section{HASIL DAN ANALISIS Metode Aritmatika/ Rata-rata Aljabar}

Metode ini adalah yang paling sederhana untuk menghitung hujan rerata pada suatu daerah. Pengukuran yang dilakukan di beberapa stasiun dalam waktu yang bersamaan dijumlahkan kemudian dibagi dengan jumlah stasiun. Stasiun yang digunakan dalam hitungan biasanya adalah yang berada dalam DAS, tetapi stasiun di luar DAS yang masih berdekatan juga bisa diperhitungkan (Triatmodjo, 2013).

Hujan rerata pada seluruh DAS diberikan oleh bentuk berikut:

$$
P=\frac{p_{1}+p_{2}+p_{3}+\cdots+p_{n}}{n}
$$

Keterangan :

$$
\begin{array}{ll}
\bar{P} & =\text { Curah Hujan Rata-rata (mm/bulan) } \\
\mathrm{Pi} & =\text { Curah Hujan ke-I (mm/bulan) } \\
\mathrm{n} & =\text { Banyak data }
\end{array}
$$

Data curah hujan bulan Januari 2015 sampai dengan bulan Maret 2016 metode aritmatika atau rata-rata aljabar disajikan pada tabel dibawah ini. 


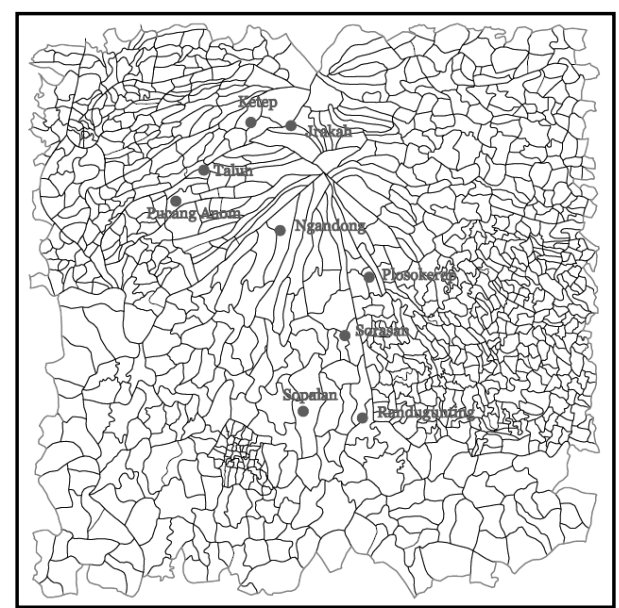

Gambar 2. Peta Metode Aritmatika

Tabel 3. Rekap Data Rata-rata Curah Hujan Metode Aritmatika atau Rata-rata Aljabar

\begin{tabular}{rlr}
\hline Tahun & Bulan & Curah hujan(mm/bulan) \\
\hline $\mathbf{2 0 1 5}$ & Januari & 428,8222 \\
$\mathbf{2 0 1 5}$ & Februari & 251,9889 \\
$\mathbf{2 0 1 5}$ & Maret & 386,7333 \\
$\mathbf{2 0 1 5}$ & April & 378,0128 \\
$\mathbf{2 0 1 5}$ & Mei & 58,61111 \\
$\mathbf{2 0 1 5}$ & Juni & 22,91111 \\
$\mathbf{2 0 1 5}$ & Juli & 0,633333 \\
$\mathbf{2 0 1 5}$ & Agustus & 0,877778 \\
$\mathbf{2 0 1 5}$ & September & 0 \\
$\mathbf{2 0 1 5}$ & Oktober & 0 \\
$\mathbf{2 0 1 5}$ & November & 128,3778 \\
$\mathbf{2 0 1 5}$ & Desember & 319,0778 \\
$\mathbf{2 0 1 6}$ & Januari & 143,0556 \\
$\mathbf{2 0 1 6}$ & Februari & 429,8333 \\
$\mathbf{2 0 1 6}$ & Maret & 313,9222 \\
\hline
\end{tabular}

\section{Metode Poligon Thiessen}

Metode ini memperhitungkan bobot dari masing-masing stasiun yang mewakili luasan di sekitar. Pada suatu luasan di dalam DAS dianggap bahwa hujan adalah sama dengan yang terjadi pada stasiun yang terdekat, sehingga hujan yang tercatat pada suatu stasiun mewakili stasiun tersebut. Metode ini digunakan apabila penyebaran stasiun hujan di daerah yang ditinjau tidak merata. Hitungan curah hujan rerata dilakukan dengan memperhitungkan daerah pengaruh dari tiap stasiun (Triatmodjo, 2013).

Secara matematis hujan rerata tersebut dapat ditulis,

$$
P=\frac{A_{1} p_{1}+A_{2} p_{2}+\cdots+A_{n} p_{n}}{A_{1}+A_{2}+\cdots+A_{n}}
$$

dengan,

$$
\begin{array}{ll}
P & =\text { hujan rerata kawasan } \\
p_{1}, p_{2}, \ldots, p_{n} & =\text { hujan pada stasiun } 1,2, \ldots, \mathrm{n}
\end{array}
$$

$$
A_{1}, A_{2}, \ldots A_{n} \quad=\text { luas daerah yang mewakili }
$$
stasiun $1,2, \ldots, \mathrm{n}$

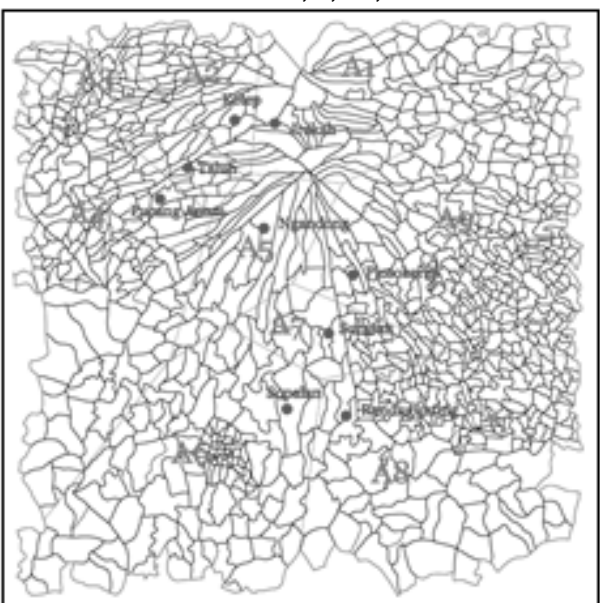

Gambar 3. Peta Metode Poligon Thiessen

Dengan melakukan pemetaan luasan wilayah metode poligon thiessen menggunakan autoCAD didapat data luasan wilayah seperti pada tabel 4 .

Tabel 4. Data Luas Poligon

\begin{tabular}{lrr}
\hline Stasiun & Poligon & Luas $\left(\mathrm{km}^{2}\right)$ \\
\hline Jrakah & A1 & 329.22 \\
Ketep & A2 & 144.22 \\
Talun & A3 & 151.22 \\
\hline Stasiun & Poligon & Luas $\left(\mathrm{km}^{2}\right)$ \\
\hline Pucang anom & A4 & 493.22 \\
Ngandong & A5 & 162.22 \\
Sopalan & A6 & 492.22 \\
Sorasan & A7 & 119.22 \\
Randugunting & A8 & 544.22 \\
Plosokerep & A9 & 467.22 \\
\hline \multicolumn{1}{c}{ Jumlah } & & 2903.00 \\
\hline \multicolumn{2}{c}{}
\end{tabular}

Rata-rata curah hujan menggunakan metode Poligon Thiesen dapat dilihat pada tabel 5 .

Tabel 5. Data Curah Hujan Metode Poligon Thiessen

\begin{tabular}{clc}
\hline Tahun & Bulan & Curah hujan (mm/bulan) \\
\hline 2015 & Januari & 454,3083 \\
2015 & Februari & 303,688 \\
2015 & Maret & 439,4225 \\
2015 & April & 358,5666 \\
2015 & Mei & 61,41568 \\
2015 & Juni & 28,13621 \\
2015 & Juli & 0,720588 \\
2015 & Agustus & 1,119585 \\
2015 & September & 0 \\
2015 & Oktober & 0 \\
2015 & November & 115,6539 \\
2015 & Desember & 271,6628 \\
2016 & Januari & 141,6099 \\
2016 & Februari & 461,9068 \\
2016 & Maret & 297,7642 \\
\hline
\end{tabular}


Gambar 4 merupakan grafik perbedaan curah hujan di area merapi menggunakan dua metode yang berbeda.

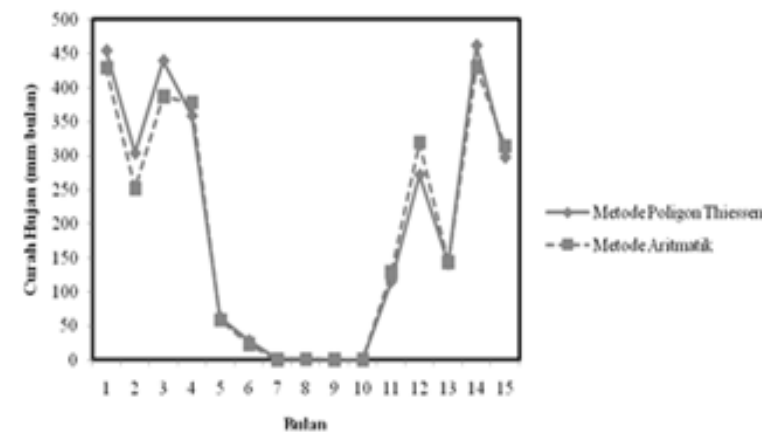

Gambar 4. Grafik perbedaan rata-rata curah hujan menggunakan dua metode yang berbeda

\section{Analisa Frekuensi}

Frekuensi merupakan jumlah kejadian dari sebuah varian, dengan analisis frekuensi akan diperkirakan interval kejadian tertentu, seperti 10 tahunan, 100 tahunan atau 1000 tahunan. Tujuan analisis frekuensi adalah mencari hubungan antara besarnya kejadian ekstrim terhadap frekuensi kejadian dengan menggunakan distribusi probabilitas (Triatmodjo, 2013).

Dalam statistik dikenal beberapa parameter yang berkaitan dengan analisis data, meliputi nilai rata-rata, simpangan baku, koefisien varian, koefisien skewnes, koefisien kurtosis (Linsley, 1996) seperti dirangkum pada table di bawah ini.

Tabel 6. Parameter statistic analisis frekuensi

\begin{tabular}{lc}
\hline \multicolumn{1}{c}{ Parameter } & Sampel \\
\hline Rata-rata & $x=\frac{\sum X_{i}}{n}$ \\
\hline Simpangan Baku & $s=\frac{\sqrt{\left(\sum\left(X_{i}-x\right)^{2}\right)}}{n-1}$ \\
\hline Varians & $s^{2}=\frac{\sum X_{i}^{2}-\frac{\left(\sum X_{i}\right)^{2}}{n}}{(n-1)}$ \\
\hline Koefisien Varians & $C_{v}=\left(\frac{x}{s}\right) 100 \%$ \\
\hline
\end{tabular}

Analisa frekuensi dari 11 stasiun hujan yang dianalisa menjadi 9 stasiun hujan saja yang dianalisa, karena 2 stasiun hujan tidak valid datanya. Berikut ini adalah analisa frekuensi 9 stasiun hujan menggunakan metode aritmatika atau rata-rata aljabar disajikan dalam tabel di bawah ini:

Tabel 7. Analisa Frekuensi Metode Aritmatika atau Rata-rata Aljabar

\begin{tabular}{cc}
\hline Bulan & Curah Hujan $(\mathrm{X})$ \\
\hline 1 & 428,8222 \\
2 & 251,9889 \\
3 & 386,7333 \\
4 & 378,0128 \\
5 & 58,61111 \\
6 & 22,91111 \\
7 & 0,633333 \\
\hline Bulan & Curah Hujan $(\mathrm{X})$ \\
\hline 8 & 0,877778 \\
9 & 0 \\
10 & 0 \\
11 & 128,3778 \\
12 & 319,0778 \\
\hline Jumlah $=$ & 1976,046 \\
\hline Mean $(\overline{\mathrm{X}})=$ & 164,6705 \\
Standar deviasi $(\mathrm{s})=$ & 174,9544 \\
Koefisien Skewness & \\
$(\mathrm{Cs})$ & 0,440236 \\
\hline
\end{tabular}

Berikut ini adalah analisa frekuensi 9 stasiun hujan menggunakan metode poligon thiessen yang disajikan dalem tabel 8 .

Tabel 8. Analisa Frekuensi Metode Poligon Thiessen

\begin{tabular}{|c|c|}
\hline Bulan & Curah Hujan (X) \\
\hline 1 & 454,3083 \\
\hline 2 & 303,688 \\
\hline 3 & 439,4225 \\
\hline 4 & 358,5666 \\
\hline 5 & 61,41568 \\
\hline 6 & 28,13621 \\
\hline 7 & 0,720588 \\
\hline 8 & 1,119585 \\
\hline 9 & 0 \\
\hline 10 & 0 \\
\hline 11 & 115,6539 \\
\hline 12 & 271,6628 \\
\hline Jumlah = & 2034,694 \\
\hline Mean $(\overline{\mathrm{X}})=$ & 169,5578 \\
\hline Standar deviasi $(\mathbf{s})=$ & 182,6641 \\
\hline Koefisien Skewness (Cs) = & 0,525883 \\
\hline Koefisien Kurtosis (Ck) = & 2,273679 \\
\hline
\end{tabular}

\section{Uji Kecocokan}

Ada dua cara yang digunakan untuk menguji apakah jenis distribusi yang dipilih sesuai dengan data yang ada, yaitu uji ChiKuadrat dan Smirnov kolmogorof (Triatmodjo, 2013). 


\section{a. Uji Chi-Kuadrat}

Uji Chi-Kuadrat menggunakan nilai $X^{2}$ yang dapat dihitung menggunakan persamaan berikut,

$$
X^{2}=\sum_{f=0}^{N} \frac{\left(O_{f}-E_{f}\right)^{2}}{E_{f}}
$$

dimana,

$X^{2}=$ nilai Chi-Kuadrat yang terhitung

$E_{f}=$ frekuensi (banyaknya pengamatan) yang diharapkan sesuai dengan pembagian kelasnya.

$O_{f}=$ frekuensi yang terbaca pada kelas yang sama

$N$ = Jumlah sub Kelompok dalam satu grup

Nilai $X^{2}$ yang diperoleh harus lebih dari nilai $X_{c r}^{2}$ (Tabel Chi-Kuadrat), untuk satu derajad nyata tertentu, yang sering diambil
$5 \%$, derajad kebebasan dihitung dengan persamaan berikut,

$D_{k}=K-(\propto+1)$

Dimana,

$D_{k}=$ Derajat Kebebasan

$\mathrm{K}=$ Banyak Kelas

$\propto=$ Banyaknya keterikatan (parameter), untuk uji Chi-Kuadrat adalah 2

Dari perhitungan data hujan menggunakan metode aritmatika atau ratarata aljabar memenuhi syarat untuk uji chi kuadrat.

1. Metode Aritmatika

Untuk menentukan jenis distribusi yang dipakai, maka hasil perhitungan curah hujan rencana periode $T$ tahun pada empat metode harus dianalisis dengan syarat jenis distribusi pada tabel 9 .

Tabel 9. Cek Syarat Distribusi Menggunakan Metode Aritmatika atau Rata-rata Aljabar

\begin{tabular}{|c|c|c|c|c|}
\hline . & Jenis distribusi & Syarat & Perhitungan & Ketera \\
\hline \multirow[t]{2}{*}{1} & Normal & $C s=0$ & Cs $=0,440236$ & Tidak Memenuhi \\
\hline & & $\mathrm{Ck}=0$ & $\mathrm{Ck}=2,087322$ & Tidak Memenuhi \\
\hline \multirow[t]{2}{*}{2} & Log normal & $\mathrm{Cs}=4,8$ & $\mathrm{Cs}=0,440236$ & Tidak Memenuhi \\
\hline & & $C k=50,7$ & $C v=0,810861$ & Tidak Memenuhi \\
\hline 3 & Gumbel & $\begin{array}{l}\mathrm{Cs} \leq 1,1396 \\
\mathrm{Ck} \leq 5,4002\end{array}$ & $\begin{array}{l}\mathrm{Cs}=0,440236 \\
\mathrm{Ck}=2,087322\end{array}$ & $\begin{array}{l}\text { Memenuhi } \\
\text { Memenuhi }\end{array}$ \\
\hline 4 & Log Pearson III & Cs bukan 0 & Cs $=0,440236$ & Memenuhi \\
\hline
\end{tabular}

Dari hasil analisis menggunakan empat jenis distribusi, maka dipilih jenis distribusi dengan simpangan terkecil yaitu Distribusi Gumbel.
2. Metode Poligon Thiessen

Untuk menentukan jenis distribusi yang dipakai, maka hasil perhitungan curah hujan rencana periode $T$ tahun pada empat metode harus dianalisis dengan syarat jenis distribusi pada Tabel 10 .

Tabel 10. Syarat Penentuan Distribusi (Data Poligon Thiessen)

\begin{tabular}{lllll}
\hline & Jenis distribusi & \multicolumn{1}{c}{ Syarat } & \multicolumn{1}{c}{ Perhitungan } & Keterangan \\
\hline $\mathbf{1}$ & Normal & $\mathrm{Cs}=0$ & $\mathrm{Cs}=0,525883$ & Tidak Memenuhi \\
& & $\mathrm{Ck}=0$ & $\mathrm{Ck}=2,273679$ & Tidak Memenuhi \\
$\mathbf{2}$ & \multirow{2}{*}{ Log normal } & $\mathrm{Cs}=4.55$ & $\mathrm{Cs}=0,525883$ & Tidak Memenuhi \\
& & $\mathrm{Ck}=44.82$ & $\mathrm{Cv}=0,787191$ & Tidak Memenuhi \\
$\mathbf{3}$ & \multirow{3}{*}{ Gumbel } & $\mathrm{Cs} \leq 1,1396$ & $\mathrm{Cs}=0,525883$ & Memenuhi \\
\multirow{2}{*}{$\mathbf{4}$} & \multirow{2}{*}{ Log Pearson III } & Cs bukan 0 & $\mathrm{Ck}=2,273679$ & Memenuhi \\
\end{tabular}


Dari hasil analisis menggunakan empat jenis distribusi, maka dipilih jenis distribusi dengan simpangan terkecil yaitu Distribusi Gumbel.

\section{b. Uji Smirnov-Kolmogorof}

Uji kecocokan Smirnov-Kolmogorof juga disebut uji kecocokan non parametrik karena pengujiannya tidak menggunakan fungsi distribusi tertentu, namun dengan memperhatikan kurva pada penggambaran probabilitas. Jarak penyimpangan terbesar merupakan nilai $\Delta_{\max }$ dengan kemungkinan dapat nilai lebih kecil dai nilai $\Delta_{k \text { ritik}}$, maka jenis distribusi yang dipilih dapat digunakan. Nilai $\Delta_{\text {kritik }}$ diperoleh dari tabel (Triatmodjo, 2013).

1. Metode Aritmatika

Untuk mengetahui pola distribusi yang sesuai digunakan uji smirnovkolmogorof. Analisis ini digunakan untuk dasar perhitungan hujan dengan berbagai periode ulang yang sesuai. Berikut ini adalah tabel hasil perhitungan uji smirnov-kolmogorof.

Uji kecocokan Smirnof-Kolmogorof menggunakan derajat kepercayaan $5 \%$ yang artinya hasil perhitungan bisa tidak diterima atau bisa diterima dengan besarnya kepercayaan $95 \%$. Dari nilai banyaknya sampel data $n=12$ dan nilai derajat kepercayaan $(\alpha)=0,05$ dengan menggunakan rumus interpolasi pada tabel Smirnov - Kolmogorof didapat nilai $D_{0}=0,32$. Dapat dilihat bahwa nilai Dmax $=0,16783$ lebih kecil dari nilai $D_{0}=0,32$, maka perhitungan distribusi dengan menggunkan metode Gumbel dapat diterima.

2. Metode Poligon Thiessen

Untuk mengetahui pola distribusi yang sesuai digunakan uji smirnovkolmogorof. Analisis ini digunakan untuk dasar perhitungan hujan dengan berbagai periode ulang yang sesuai. Berikut ini adalah tabel hasil perhitungan uji smirnov-kolmogorof.

Uji kecocokan Smirnof-Kolmogorof menggunakan derajat kepercayaan $5 \%$ yang artinya hasil perhitungan bisa tidak diterima atau bisa diterima dengan besarnya kepercayaan 95\%. Dari nilai banyaknya sampel data $n=12$ dan nilai derajat kepercayaan $(\alpha)=0,05$ dengan menggunakan rumus interpolasi pada tabel Smirnov - Kolmogorof didapat nilai $D_{0}=0,32$. Dapat dilihat bahwa nilai Dmax $=0,16783$ lebih kecil dari nilai $D_{0}$ $=0,32$, maka perhitungan distribusi dengan menggunkan metode Gumbel dapat diterima.

\section{Intensitas - Durasi - Frekuensi (IDF)}

Intensitas-Durasi-Frekuensi biasanya diberikan dalam bentuk kurva yang memberikan hubungan antara intensitas hujan ssebagai ordinat, durasi hujan sebagai absis dan beberapa grafik menunjukkan periode ulang (Triatmodjo, 2013).

Analisis IDF dilakukan untuk memperkirakan debit puncak di daerah tangkapan kecil, seperti dalam perencanaan sistem drainase kota dan jembatan. Di daerah tangkapan kecil, hujan deras dengan durasi singkat yang jatuh di berbagai titik pada seluruh daerah tangkapan hujan dapat terkonsentrasi di titik kontrol yang ditinjau dalam waktu yang bersamaan, yang dapat menghasilkan durasi singkat. Hujan deras dengan durasi singkat (5, 10 atau 15 menit) dapat diperoleh dari kurva IDF yang berlaku untuk daerah yang ditinjau (Triatmodjo, 2013).

Analisis IDF dilakukan untuk memperkirakan debit aliran puncak berdasar data hujan titik (satu stasiun pencatat hujan). Data yang digunakan adalah data hujan dengan intensitas tinggi yang terjadi dalam waktu singkat, seperti hujan $5,10,15, \ldots, 120$ menitan atau lebih. Untuk itu diperlukan data hujan dari stasiun pencatat hujan otomatis (Automatic Rainfall Recorder) (Triatmodjo, 2013).

Hitung Intensitas hujan untuk beberapadurasi waktu menggunakan rumus Mononobe (Data Aritmatika).

$I=\frac{R_{24}}{24}+\frac{24^{\frac{2}{3}}}{t}$ 
Tabel 11. Tabel IDF dengan Metode Aritmatika

\begin{tabular}{ccccc}
\hline \multirow{2}{*}{$\begin{array}{c}\text { Durasi } \\
\text { (Jam) }\end{array}$} & \multicolumn{3}{c}{ Curah Hujan Harian Maksimum 24 Jam (R24) (mm/24 jam) } \\
\cline { 2 - 5 } & \multicolumn{2}{c}{ 5 Tahun } & Intensitas Hujan Rencana & dengan rumus Mononobe (mm/Jam) \\
\hline $\mathbf{0 , 1 6}$ & 758,079359 & 1047,382 & 1436,285 & 1717,125 \\
$\mathbf{0 , 2 5}$ & 485,1707898 & 670,3243 & 919,2226 & 1098,96 \\
$\mathbf{0 , 3 3}$ & 367,5536286 & 507,8215 & 696,3808 & 832,5453 \\
$\mathbf{0 , 5}$ & 242,5853949 & 335,1622 & 459,6113 & 549,4799 \\
$\mathbf{1}$ & 121,2926974 & 167,5811 & 229,8057 & 274,74 \\
$\mathbf{2}$ & 60,64634872 & 83,79054 & 114,9028 & 137,37 \\
$\mathbf{4}$ & 30,32317436 & 41,89527 & 57,45141 & 68,68499 \\
$\mathbf{5}$ & 24,25853949 & 33,51622 & 45,96113 & 54,94799 \\
$\mathbf{1 2}$ & 10,10772479 & 13,96509 & 19,15047 & 22,895 \\
$\mathbf{2 4}$ & 5,053862394 & 6,982545 & 9,575236 & 11,4475 \\
\hline
\end{tabular}

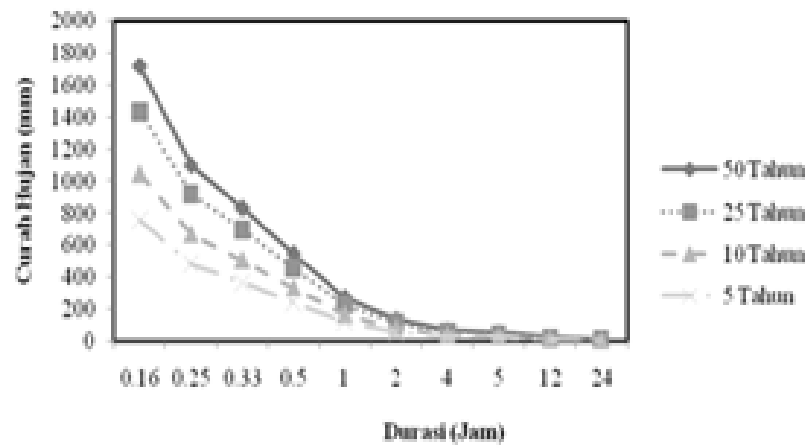

Gambar 5. Grafik Lengkung Intesitas Hujan

Tabel 12. IDF dengan data metode Poligon Thiessen

\begin{tabular}{|c|c|c|c|c|}
\hline \multirow{3}{*}{$\begin{array}{l}\text { Durasi } \\
\text { (Jam) }\end{array}$} & \multicolumn{4}{|c|}{ Curah Hujan Harian Maksimum 24 Jam (R24) (mm/24 jam) } \\
\hline & 5 Tahun & 10 Tahun & 25 Tahun & 50 Tahun \\
\hline & \multicolumn{4}{|c|}{ Intensitas Hujan Rencana dengan rumus Mononobe (mm/Jam) } \\
\hline 0,16 & 786,3521189 & 1088,403208 & 1494,445 & 1787,66 \\
\hline 0,25 & 503,2653561 & 696,5780529 & 956,4445 & 1144,102 \\
\hline 0,33 & 381,2616334 & & 724,5792 & 866,7441 \\
\hline 0,5 & 251,6326781 & 348,2890264 & 478,2223 & 572,0511 \\
\hline 1 & 125,816339 & 174,1445132 & 239,1111 & 286,0255 \\
\hline 2 & 62,90816951 & 87,07225661 & 119,5556 & 143,0128 \\
\hline 4 & 31,45408476 & 43,5361283 & 59,77778 & 71,50638 \\
\hline 5 & 25,16326781 & 34,82890264 & 47,82223 & 57,20511 \\
\hline 12 & 10,48469492 & 14,51204277 & 19,92593 & 23,83546 \\
\hline 24 & 5,24234746 & 7,256021384 & 9,962964 & 11,91773 \\
\hline
\end{tabular}

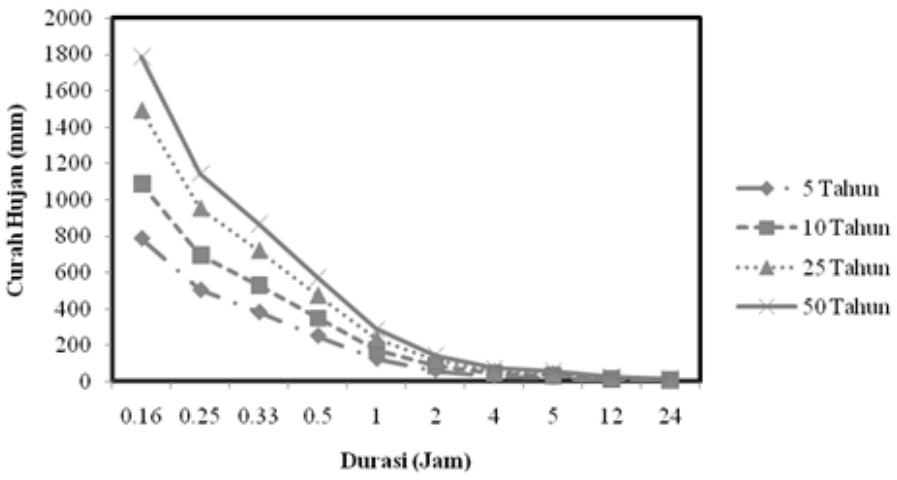

Gambar 6. Grafik Lengkung Intensitas Hujan 


\section{KESIMPULAN}

Berdasarkan hasil analisis, maka diperoleh kesimpulan sebagai berikut:

1. Dari 11 (sebelas) data stasiun hujan yang berada di Area Merapi, terdapat 2 (dua) data stasiun hujan yang tidak valid yaitu data pada stasiun hujan Stabelan dan stasiun hujan Sukorini, sehingga data pada stasiun hujan tersebut tidak digunakan dalam analisis perhitungan selanjutnya, dengan alasan data tidak valid. Pola distribusi curah hujan di Area Merapi baik menggunakan Metode Aritmatika atau Rata-rata Aljabar maupun Metode Poligon Thiessen menunjukan pola distribusi yang cocok adalah Distribusi Gumbel.

2. Dengan menggunakan metode aritmatika atau rata-rata aljabar, hujan rata-rata terbesar di area Merapi tahun 2015 pada bulan Januari, yaitu sebesar 604,67 $\mathrm{mm} /$ bulan, dan terkecil pada bulan Oktober dan November, yaitu sebesar $0 \mathrm{~mm} / \mathrm{bulan}$. Pada tahun 2016 didapatkan hujan ratarata terbesar di area Merapi pada bulan Maret yaitu sebesar 429,83 mm/bulan dan terkecil pada bulan Februari yaitu sebesar $143,06 \mathrm{~mm} /$ bulan. Sedangkan dengan menggunakan metode poligon thiessen, hujan rata-rata terbesar di area Merapi tahun 2015 pada bulan Januari, yaitu sebesar 504,462 mm/bulan, dan terkecil pada bulan Oktober dan November, yaitu sebesar 0 mm/bulan. Pada tahun 2016 didapatkan hujan rata-rata terbesar di area Merapi pada bulan Maret yaitu sebesar $461,9068 \mathrm{~mm} / \mathrm{bulan}$ dan terkecil pada bulan Februari yaitu sebesar 141,9068 $\mathrm{mm} /$ bulan.

Saran-saran yang dapat menjadi pertimbangan dalam studi selanjutnya antara lain:

1. Penggunaan metode atitmatika dalam analisa curah hujan wilayah sangat sesuai apabila digunakan di kawasan-kawasan yang datar (rata) dan DAS-DAS dengan jumlah penakar hujan yang besar yang didistribusikan secara merata pada lokasilokasi yang mewakili. Kekurangan dari penggunaan metode aritmatika ini adalah luasan wilayah DAS dianggap sama, padahal itensitas curah hujan di suatu wilayah DAS belum tentu sama.

2. Metode Poligon Thiessen sesuai digunakan untuk kawasan-kawasan dengan jarak penakar-penakar hujan yang tidak merata dan metode ini tidak memperhitungkan topografi. Kekurangan dari metode ini adalah memerlukan stasiun-stasiun pengamat di dekat kawasan penakar hujan dan penambahan atau pemindahan suatu stasiun pengamat akan mengubah seluruh jaringan.

\section{DAFTAR PUSTAKA}

Agustin, W. (2010). Pola Distribusi Hujan JamJaman di Sub DAS Keduang. Surakarta: Skripsi Universitas Sebelas Maret.

Girsang, F. (2008). Analisis Curah Hujan Untuk Pendugaan Debit Puncak dengan Metode Rasional pada DAS Belawan Kabupaten Deli Serdang. Sumatera Utara: Skripsi Universitas Sumate ra Utara.

Linsley, R. K., Kohler, M. A., Paulhus, J. L., \& Hermawan, Y. (1996). Hidrologi untuk Insinyur (Edisi Ketiga). Jakarta: Penerbit Erlangga.

Seyhan, E. (1990). Dasar-Dasar Hidrologi. Yogyakarta: Gajah Mada University Press.

Triatmodjo, B. (2013). Hidrologi Terapan. Yogyakarta: Beta Offset Yogyakarta.

Tjasyono, B. (2004). Klimatologi. Bandung: Penerbit ITB.Bintarto, R., 1984. Interaksi Desa-Kota. Jakarta: Ghalia Indonesia. 
Lashari, dkk / Jurnal Teknik Sipil \& Perencanaan 19 (1) (2017) 39 - 48 